\title{
Pricing and Market Results of Greek Coastal System after Cabotage Privilege Removal (2002-2010): The Example of European and Global Aviation
}

\author{
Ioannis Sitzimis ${ }^{1}$
}

\begin{abstract}
The purpose of this article is to compare Greek coastal shipping and aviation industry immediately after their liberalization. It focuses mainly on fare configuration analysis of domestic and global aviation to compare the conclusions with Greek coastal market. This is an innovative approach as there has been no such research effort on this issue in the past. The importance of our analysis lies to a large extent in exploring the improvement or deterioration of passenger services for the two modes of transport following the lifting of cabotage privilege. It can be a yardstick for those researchers who want to know in advance what could happen in the first years of liberalization in a transport industry.

The analysis results show that the institutional framework and the economic market conditions in two industries characterized by both similarities and differences.
\end{abstract}

JEL classification numbers: R40, M21, L50.

Keywords: Global and European Aviation, Greek coastal shipping, Market liberalization, Lifting of cabotage privilege, Fares, Passenger service.

\footnotetext{
${ }^{1}$ Department of business administration \& Tourism, Hellenic Mediterranean University, Heraklion, Greece.
}

Article Info: Received: September 26, 2021. Revised: October 12, 2021.

Published online: October 15, 2021. 


\section{Introduction}

Air transport is an important and sensitive sector of a country's economic activity. The development of air transport since the beginning of the 20th century went through various stages. Followed both the technological development and the need of states, concerning national and international transport, for uniform regulatory rules. The aim was to ensure that there were no differences between national laws on issues such as the liability of air carriers and the passengers' safety.

The liberalization of an "adjoining" industry, such as aviation (AVI), can provide satisfactory information on the effects of liberalization in Greek coastal shipping (GCS). The removal of cabotage ${ }^{2}$ privilege in air transport was preceded a few years before the liberalization of coastal shipping, offering experience of the operation of an "open" market in the environment of a transport service. The choice of this industry as a yardstick is not accidental. On the one hand, the institutional framework of the two industries, as far as liberalization is concerned, is similar and, on the other hand, the similarities between the two modes of transport, in terms of economic analysis, are obvious.

In Greece, the waiving of Cabotage privilege for both markets was done with a time preparation of nine and twelve years respectively, while their microeconomic form resembles. These are mainly oligopolistic, duopolistic or even monopolistic markets (per line) (Goulielmos and Sitzimis, 2012; Rubin and Jou, 2005). State intervention is mainly limited to "barren" lines ${ }^{3}$, where subsidies continued after liberalization. There is strong seasonality with an increase in occupancy rates for the ship and the plane between March and October (Sitzimis, 2021a). The main reason for the shift in capacity demand for both modes is the fluctuation of tourist flows. The travel time in both cases is strictly defined and on some routes there is substitution between them (Spathi, 2005). The frequency of services is mainly determined on demand basis, availability and means of transport capacity. There is high technology in new ships and airplanes, with significant flexibility in the operation of routes (possibility of multiple routes on the same day).

The purpose of this article is to compare GCS and AVI immediately after their deregulation. It focuses mainly on fare configuration analysis of domestic and global aviation in order to compare the conclusions with Greek coastal market.

\footnotetext{
2 The word "cabotage" means the transport of persons and goods between ports of the same country. A narrower interpretation is the right of carriage to belong only to ships flying the flag of a specific country. Therefore, the removal of "cabotage" means the removal of this right. The same word is used in air transport.

3 According to Law 2923/2001, the Greek State characterizes as "barren" those lines for which there is no expression of interest for their operation from coastal companies. The remaining coastal lines are classified as "viable".
} 
The research questions answered and concern the period 2002-2010, are:

- What are the overall implications of the AVI market liberalization at European, global and domestic level and how are they related to GCS?

- Are there commonalities in pricing results of AVI and GCS after their liberalization?

This is an innovative approach as there has been no such research effort on this issue in the past. The importance of our analysis lies to a large extent in exploring the improvement or deterioration of passenger transport services for the two modes of transport following the lifting of cabotage privilege. Also it can be a yardstick for those researchers who want to know in advance what could happen in the first years of liberalization in a transport industry.

\section{The institutional framework of liberalization for the two means of transport}

The regime of bilateral state agreements, established by the "Chicago International Convention" in 1944, based on which scheduled air transport operated worldwide, gradually gave way to a regime of liberalization of air transport. It began with the "deregulation" of the U.S.A AVI market in 1978, which was later followed by the European market (1999) (Schipper and Rietveld, 1997).

The liberalization of air transport in European Union (EU) area was implemented gradually, on the one hand, by measures taken in 1987 (Directives 87/601/EC and 87/602/EC) and in 1990 (Regulations 2342/1990, 2343/1990 and 2344/1990) and, on the other hand, by Regulations 2407/1992, 2408/1992 and 2409/1992 (Lainos, 1999). It was initially limited, since from $1 / 4 / 1993$ to $1 / 4 / 1997$ air carriers of EU, with a valid operating license, had access to scheduled air routes with certain restrictions on the operation of services and the capacity offered (Brueckner et al, 1997).

The liberalization of air transport, the so-called "Open Skies", concerned both the free access of EU air carriers to passenger and freight transport between Member States and within each Member State (Peterson, 2008). Regulation 2409/1992 of the European Council (EC) also established the free configuration of air fares. Since 1 April 1997, the complete liberalization of air transport has taken place, when in mainland Greece all EU air carriers have had the right of access to scheduled (or non-scheduled - charter) flights. After 30 June 1998, with the complete abolition of cabotage privilege, there was free access with regular flights to Greek islands as well. This liberalization in EU was followed by an attempt to reorganize the aviation market on commercial exploitation issues, such as the system of reservations and ground handling of aircraft (Lainos, 1999).

It is worth noting two elements of the above, which are of great concern to GCS:

(1) The global conviction for the uniform regulatory rules that should govern national and international transport (in the context of creating competitive 
conditions on the world market) and which was the one that essentially led to the lifting of cabotage privilege, and (2) the gradual rather than immediate liberalization of GCS. The GCS policy, in the period up to 2002, was a policy of regulation by the state, with degradation and disregard of competition and demand (mainly after 1976 and until 1998) and with extensive opacity in terms of quantity and quality, as well as the cost of the services provided (Goulielmos and Sitzimis, 2012). The political objectives pursued were not clear (Sitzimis, 2012). The Ministry of Shipping and Island Policy acted highly diplomatically, trying to satisfy all stakeholders. It attempted the best possible interconnection of the islands, the protection of the coastal companies (with the liberalization of coastal transport), the protection of workers in coastal transport (with the prohibition of foreigners - non EU workers employment), the partial "financing" of the Naval Veteran Fund (fee in favor of third parties on ticket price), the subsidy of "barren" lines at the expense of "viable" lines (with a surcharge of 3\%) and the cross-subsidization of winter coastal transport, with a charge to passengers of summer season (with the mandatory operation of coastal companies for nine or ten months and coverage of staff costs for the whole year) (NBG, 2009).

Law 2932/2001 essentially attempted to direct the institutional framework of GCS' operation towards the rules set by the European Community Regulation (ECR) of the EC of the European Economic Community 3577/1992 (Goulielmos and Sitzimis, 2014). GCS acquired some basic characteristics of free and unhindered competition. However, there was a mandatory provision of public services when market distortions were created that affected vulnerable social groups (Spathi, 2005).

The abolition of "feasibility licenses" 4 and the possibility of free access to the market for Greek and EU coastal companies should be reported (Psaraftis, 2006).

However, there were still several deviations from the ECR. Specifically:

(a) strict bureaucratic procedures for the approval of routing on a coastal line,

(b) determination of both economy class and private vehicles fares by the state,

(c) the existence of a specific age limit for the withdrawal of ships,

(d) state port control with refusal of charging free contributory fees,

(e) maintenance of detention for ships,

(f) obligation to serve the approved coastal lines for at least ten months,

(g) recruitment of only Greek or EU crews and

(h) compliance with Greek standards in the configuration of the internal spaces of ships.

The main consequence of these deviations was the non-entry of EU coastal companies into GCS and the non-willingness of coastal companies' owners (CSO) for investments, in order to renew the existing number of ships. At the same time,

4 These are licenses that have been in force since 1976 and determined the entry or not of a company (ship) in a coastal line. The licensing system indirectly did not allow the entry of new coastal companies (ships) on the same line. The common argument for "feasibility licenses" is that coastal shipping owners would never accept the risk of undertaking a shipping operation without a controlled guarantee to prevent the entry of new companies. 
port services deteriorated, resulting in inconvenience to passengers.

The situation improved significantly in 2006 (Psaraftis, 2006). Fares fully liberalized for all classes, the problems arising from insurmountable bureaucratic procedures alleviated, the age limit for the withdrawal of ships abolished, the conditions of the Stockholm Conventions complied with, and an effort made to improve the image of ports technologically and substantially.

\section{The effects of liberalization on global and Greek AVI and their connection to GCS}

\subsection{The impact of cabotage privilege removal in AVI}

The liberalization of air transport in U.S.A in 1978 and in Europe in 1999, led to the creation of a new regulatory framework in the market. At the same time, the demand for air transport services showed a significant increase, resulting in a knockon effect on the organization of companies and airports (Holloway, 2006).

In all liberalized markets, there was an obvious "price discrimination" on tickets and discounts (Forsyth, 1997). Not all airlines chose to serve both the "professional" and the "leisure" market by applying this distinction. Some chose to simply impose low ticket prices on a more general basis but failed. Particular preference was for high-demand lines, where the policy of "cream skimming" was applied. That is, activation in peak periods and withdrawal in the rest. Moreover, market segments such as those of "professional" capacity demand offered high returns.

More generally, tickets' structure was aimed at making more efficient use of existing capacity. Discounts were given during non-peak periods, in cases of early booking (but with restrictions to avoid cancellations) and to customers who were not willing to pay particularly high prices for additional comfort on board. Of course, the configuration of fares was different from a perfect competitive market. In other words, competition was not so intense as to avoid price discrimination. However, this kind of corporate behavior did not necessarily reduce efficiency.

This distinction is liable to enhance profitability, and this is the case in transport markets (Frank, 1983). This is due to economies of scale, which achieve a reduction in average variable costs over the long term as the scale of production increases (Sitzimis, 2021b). If, for say, larger means of transport, or a higher frequency of services, or a combination of the two are used.

In U.S.A. (after liberalization) "hub-and-spoke" networks were developed (Douglas and Miller, 1974). This had serious consequences both on the frequency of services and on the routes provided to passengers. The service network as a whole was strengthened ( $\mathrm{Fu}$ et al, 2010). Traditional air carriers, through the radial network, increased their occupancy and maintained regular air connections to several destinations (OLP, 1996-2007). Low cost carries (LCCs) turned to the point to point network and preferred secondary airports in order to cope with the intense competition. They were helped by the increased concentration of flights at central airports, the corresponding delays and the high service charges. Also, characteristic were the alternations of networks between airlines belonging to the same strategic 
alliances (Oum et al, 2000). However, due to accessibility options at secondary, regional airports, areas of reduced air demand (remote islands) were left without air service. The direct consequence was the public service obligation (PSO) on those routes (Wittman et al, 2016).

The results worldwide in the field of quality are indistinguishable. According to some researchers there have been positives, but few. Papatheodorou (2008) points out that the overall trend is rather negative due to pressures to reduce costs and the continuous increase in air traffic volumes. This has created problems of overcrowding and delays at several central airports. LCCs and charter carriers have minimized the services provided to passengers (frills). Traditional air carriers have made a "quality distinction" by providing different levels of service inside the plane (economy and business class). Innovative has been the development of all-business class companies that provide excellent quality services to their passengers (IATA, 2007). However, the lifting of the various restrictions led to new routes and to the provision of new tourist destinations (Seetanah et al, 2019). This, combined with the drop in fares, made the trip accessible to a large portion of the population and led to mass tourist movements (charter flights and LCCs) (Bieger and Wittmer, 2006).

Using the example of the American market (it has been thoroughly researched due to the passage of several years since liberalization), studies have shown that liberalization led to an increase in economic efficiency (mainly due to higher occupancy rates and lower costs per passenger mile) (Caves et al, 1987). The rate of this increase in 1983 was $10 \%$ higher than initially expected. Subsequent studies (Morrison and Winston, 1995) showed that in addition to improving the quality of the service provided, ticket prices in 1993 in this market were down by $22 \%$, compared with specific trend projections made. There have also been signs of an increase in the "consumer surplus". Koran (1983) showed a \$15 to \$20 increase in the surplus per trip, keeping air profits intact. The increase was due to the fact that the price of tickets before liberalization was above the "optimal" level. With liberalization, prices fell, exceeding the deterioration of quality and the "surplus of producers" remained stagnant, as the decrease in prices was not due to a decrease in average costs.

However, the lifting of Cabotage privilege (mainly in U.S.A. in 1978 but also in Europe in 1999), according to several authors, did not lead to intense competition, measured by the number of competitors, as expected. Johnson (1995) argues that the entry of new companies was difficult, with the exception of the first years of liberalization. They were mainly smaller companies, whose role was purely complementary to that of the large airlines in the sector. The existing companies diagnosed that they were long-term rather than short-term competitors, resulting in a "gentlemen's agreement" to increase ticket prices. Some of them chose to dominate the "hubs" and others the infrastructure. In terms of prices, companies were able to price above marginal costs as a consequence of their higher efficiency, although these costs were not particularly high in this industry due to the intense economies of scale and the high fixed costs. The cooperation between the 
companies was mainly about price levels and not about decisions on aircraft capacity levels. There was over-investment in capacity, and the prospect of maximizing profit in the short term, with the ultimate goal of long-term returns, was ignored. Of course, there are also researchers who disagree (Button, 1998; Fu et al, 2010) stressing that there was strong competition within the AVI industry. It is true that several national carriers lost the privileges of protectionism and were either driven out of the market or led to privatization (see Olympic Airways in Greece). To sum up, better and more efficient use of existing capacity, increased efficiency and reduced costs were the main benefits of the removal of Cabotage privilege in the American market in 1978. In European market, the liberalization led to higher profits (but lower than expected), with variations compared to the American market, due to qualitative differences, differences in profitability and market conditions. The lack of a significant number of competitors, especially new entrants, means that the pressure to reduce costs to a minimum is less strong than North American routes.

\subsection{The impact of cabotage privilege removal in GCS}

In GCS, initially expected a drop in the number of routes after the liberalization, due to the reduction of coastal fleet and the effort of CSO both to increase the occupancy rates of ships and reduce the unit cost (Goulielmos and Sabrakos, 2002). The average cost (AC) at GCS is particularly high and even higher than the marginal cost (MC) (Sitzimis, 2021b-c). This means that the tendency to reduce AC was normal. The real objective was to increase occupancy rates on existing routes or to reduce routes. Curiously, the investigation of ships' arrivals (in number and GRT) for the port of Piraeus, between 2002-2008 (Table 1), led us to ambiguous conclusions.

During the first year of full liberalization (2006), the immediate and expected reaction of CSO was, naturally, the reduction of routes (both in number of ships and GRT) (table 1). For this reason, the number of GCS's itineraries from the port of Piraeus on the days of Holy Week (Easter) for the years 2004-2006 did indeed decrease (Elstat, 2000-2010). 
Table 1: Domestic passenger ships to arrive (in number and GRT) at the port of Piraeus (2002-2008)

\begin{tabular}{|c|c|c|c|c|}
\hline Year & Number of ships to arrive & $\%$ change & GRT & $\%$ change \\
\hline 2002 & 21,651 & & $73,082,876$ & \\
\hline 2003 & 20,409 & \multirow{3}{*}{$5.09 \%$} & $78,582,183$ & \multirow{3}{*}{$-5.32 \%$} \\
\hline 2004 & 23,823 & & $80,305,715$ & \\
\hline 2005 & 21,448 & & $74,405,435$ & \\
\hline 2006 & 19,337 & \multirow{3}{*}{$9.86 \%$} & $73,622,570$ & \multirow{3}{*}{$-0.18 \%$} \\
\hline 2007 & 22,841 & & $80,443,001$ & \\
\hline 2008 & 21,288 & & $73,493,024$ & \\
\hline Average & 21,542 & & $76,276,401$ & \\
\hline
\end{tabular}

Source: Elstat, 2000-2010.

Deepening, however, we found that during the partial liberalization (2003-2005) there was an increase in number of ships' arrivals (5\%), but not in GRT (-5\%).

During the period of full liberalization (2006-2008) there were larger increases in number $(+10 \%)$ and smaller increases in GRT $(-0.2 \%)$. More generally, after the liberalization (2003-2008), the number of ships' arrivals increased by about $4 \%$, while in GRT decreased by $6 \%$. Consequently, the number of routes was increased by ships of smaller tonnage. This means, on the one hand, for users' inability to travel during the hours they wish due to the over-occupancy of the available ships and, on the other hand, a different strategic approach of coastal companies in relation to the routing areas of their fleet. The increase in arrivals of ships took place mainly on high-demand lines (Sitzimis, 2012).

Although the lack of statistical data for all coastal companies is a fact, there was a decrease in the number of routes - nautical miles travelled (at least for companies Nel Lines, Hellenic Seaways and Blue Star Ferries), after the partial market liberalization in November 2002 and until the full liberalization in 2006 (Sitzimis, 2012). Between 2006-2007 for all three companies there were increases in routes, a result consistent with the analysis set out in the preceding for the port of Piraeus. It is striking that for Blue Star Ferries, while, between 2005-2006, the number of routes decreased, destinations increased (without changing the company's fleet). It was the company's choice to reduce routes on non-profitable routes and place its ships in more profitable ones, thus increasing the number of accessible ports ("cream skimming") (Sitzimis, 2021c). In the context of a more thorough analysis, looking at the months that show the highest passenger traffic (peak months-summer) the results are the same as before. The number of routes showed a marginal increase between 2006 and 2008.

In 2009 the situation may have changed under the pressure of the economic recession and not because of the liberalization of the market. Routes decreased in 2009 , with a percentage change between 2007-2009 of about -3\%. It is characteristic that during the period 1-20/7/2010, 525 routes were executed (4 less than the 
corresponding period of 2009) to the Aegean islands, Crete and Dodecanese (OLP, 1996-2007; Sitzimis, 2012).

Also, during the years of liberalization, ship sales were recorded by the five main companies of GCS (based on their turnover) with their number rising significantly if we also consider the number of ships of their subsidiaries. Conventional ships were reduced by 19 and high-speed ferries by 8 (2002-2009) (Table 2). One would assume that it was an effort of the CSO to improve the quality of their services provided (renewal of their fleet), but it is not.

The reasons for the sale of these ships were several (Sitzimis, 2012; XRTC, 2005; 2006; 2009). Initially, there were sales driven by the reduction of the maximum age limit from 35 years to 30 by 2008 under law 2931/01. Also, sales that came as a result of the expanding financial pressures of companies for the annual repayments of their loans. There was an over-capacity (passengers, vehicles) on specific coastal lines resulting in low occupancy rates. The companies were unable to continue the impressive investment program in which they proceeded during the glorious era of the Athens Stock Exchange (ASE) (1999). As a result, they failed to complete their investment plans successfully and were led to the restructuring of their loans. Their financial constraints, as well as the unclear environment in which they operated, were prohibitive factors for investment in new buildings. It is characteristic that regarding the age of their ships, there was a continuous increase after the year 2005 (the percentage increase, between 2003-2009, in the average age of ships was approximately 5\%) (Sitzimis, 2012). Although the CSO mainly replaced conventional ships, it is obvious that they didn't renew their fleet.

Table 2: The variation of the fleet (in number) of the five main coastal companies of GCS (2000-2009)

\begin{tabular}{|c|c|c|c|}
\hline Year & $\begin{array}{c}\text { Conventional } \\
\text { ships }\end{array}$ & $\begin{array}{c}\text { High speed } \\
\text { ships }\end{array}$ & $\begin{array}{c}\text { Total number } \\
\text { of ships }\end{array}$ \\
\hline & & & \\
\hline 2000 & 64 & 26 & 90 \\
\hline 2001 & 57 & 28 & 85 \\
\hline 2002 & 62 & 28 & 90 \\
\hline 2003 & 57 & 27 & 84 \\
\hline 2004 & 48 & 26 & 74 \\
\hline 2005 & 40 & 22 & 62 \\
\hline 2006 & 38 & 23 & 61 \\
\hline 2007 & 39 & 23 & 62 \\
\hline 2008 & 37 & 23 & 60 \\
\hline 2009 & 43 & 20 & 63 \\
\hline Average & 49 & 25 & 74 \\
\hline
\end{tabular}

Source: Sitzimis, 2012. 
Before the complete liberalization of the market, the number of passengers handled, showed a significant increase in the whole period 1996-2006 (more than 65\%), while the average annual increase amounted to 71.8\% (Table 3) (OLP, 1996-2007). A small decrease occurred between 2003-2004, mainly due to the climate of terrorism that prevailed in Europe (Spain-England). The transport traffic of vehicles (private vehicles and trucks) also showed a continuous increase for the whole period 1998-2006 (average increase of 58.1\%). The largest increase is in 2001 and 2003 (about 11\%) while in 2007 there is an increase of about $3 \%$ corresponding to about 27,000 vehicles. $62 \%$ of the wheeled vehicles $(612,000)$ were passenger cars and the remaining 38\% were trucks $(364,000)$ and buses $(9,000)$ (OLP, 1996-2007). These increases were mainly due to the development of tourism in insular Greece, as well as to the decentralization of certain sectors (e.g. establishment of universities), which brought about an increase in GDP of island prefectures, an increase in permanent population and an increase in passenger and vehicle traffic (Spathi, 2005). The increase in routes and the direct connection of many islands with the major ports of the mainland made a lot of islands more accessible to tourism (XRTC, 2009). At the same time, the islands were more dependent on the central ports (Piraeus, Rafina, Lavrio, Agios Konstantinos), where all the economic and social activity of the country is concentrated, both for economic reasons (employment and professional activities or travel for holidays) and for other reasons (more hospitals and schools).

It is characteristic that between 1996-2002 (years before liberalization) passenger traffic increased by $63.8 \%$, between 2003-2006 (years of partial liberalization) it increased by 5\% and between 2006-2008 (years of full liberalization) it decreased by $2.2 \%$ (table 3 ). The decrease observed in the years 2007 and 2008 is due to the decline in the per capita income of Greeks and the over-indebtedness of Greek households (first symptoms of the global economic recession of October 2008). However, the liberalization of GCS also has a significant share of responsibility, as between 2007-2008 we had a decrease in the number of ships, both in number and in GRT (table 1). Something similar happens for vehicles, where the corresponding percentages are $36.1 \%, 4 \%$ and $3.5 \%$. The declining growth rate here is distinct. 
Table 3: Passenger and vehicle traffic in GCS (from the port of Piraeus) between the years 1996-2008

\begin{tabular}{|c|c|c|c|c|}
\hline Year & Passengers & $\%$ change & Vehicles & $\%$ change \\
\hline 1996 & $6,791,636$ & \multirow{7}{*}{$63.8 \%$} & - & \multirow{7}{*}{$36.1 \%$} \\
\hline 1997 & $7,407,129$ & & - & \\
\hline 1998 & $8,364,688$ & & 607,674 & \\
\hline 1999 & $8,895,395$ & & 669,749 & \\
\hline 2000 & $9,920,868$ & & 700,797 & \\
\hline 2001 & $10,057,695$ & & 781,153 & \\
\hline 2002 & $11,125,773$ & & 826,746 & \\
\hline 2003 & $11,713,269$ & \multirow{4}{*}{$5.0 \%$} & 923,369 & \multirow{4}{*}{$4.0 \%$} \\
\hline 2004 & $11,159,274$ & & 948,624 & \\
\hline 2005 & $11,621,715$ & & 962,938 & \\
\hline 2006 & $11,668,647$ & & 960,412 & \\
\hline 2007 & $11,572,678$ & \multirow{2}{*}{$-2.2 \%$} & 987,133 & \multirow{2}{*}{$3.5 \%$} \\
\hline 2008 & $11,413,843$ & & 993,756 & \\
\hline $\begin{array}{c}\text { Average } \\
(1996-2006)\end{array}$ & $9,884,190$ & $71.8 \%$ & 820,162 & $58.1 \%$ \\
\hline
\end{tabular}

Source: OLP 1996-2007, Sitzimis 2012.

Note: As vehicles we consider the sum of trucks, passenger cars and buses / minibuses. The analysis concerns six coastal lines with high transport traffic over time (those of the Argosaronic Gulf, Crete, Cyclades, Paronaxia, Dodecanese and the rest of the Islands).

In practice, the free routing of ships led to an increase in applications of CSO for the most profitable routes. As a result, several islands of low demand were not served adequately (Lekakou, 2007; Sitzimis, 2012). The definition of the characteristics of ships, on these lines, was based on specific required qualifications. The list of qualifications counted was particularly comprehensive, in contrast to high-demand lines. These low demand itineraries were in many cases problematic, the travel times were very long and the arrival and departure of ships was at nonpeak times. At the same time, the delays, due to many intermediate approaches, created intense problems both to their network design and the calculation of the rational capacity supply required to serve residents. As a result, their economic development and viability were compromised (Psaraftis, 2006). This poor or even non-existent coastal connection, resulted in many Aegean islands facing problems of supply, medical care and connection with the mainland (Spathi, 2005). The discontinuity of connections between the islands worsened during the winter season compared to the summer season, as the demand in winter presented a significant drop (about 80\%) compared to the summer season. It is noteworthy that a large percentage of summer island connections did not exist during the winter season. The transportation problems of islands during the winter season, worsened due to the bad weather conditions in the seas. The cancellation of itineraries created significant difficulties in everyday life and often in inhabitants' health of several Aegean islands (Lagoudis et al, 2011). 
Moreover, after the liberalization of GCS, the network of coastal transport became even more complicated (Lekakou, 2007). This was due to the accumulation of ships on the most profitable lines, the lack of ships in the rest and the effort of the Greek state to limit the cost of subsidies by covering only the necessary connections. As a result, there were severe transport problems. The complexity of the network, the reduced intervention of the state in its design and the ability of CSO to create or abolish connections according to their business interest contributed to this. Furthermore, the radial configuration of coastal lines from the mainland port caused significant transport malfunctions, such as delays and overcrowding in the port (especially during peak periods) (Goulielmos and Sabrakos, 2002). It is obvious, therefore, that the planning and operation of itineraries was not effective. Local communities, shipping companies and the state had diametrically opposed goals (Lekakou, 2007). The companies looked almost exclusively to serve islands with high tourist traffic (ignoring the passengers of "barren" islands where they used low operating cost ships - old conventional ships) while the state sought the lowest possible subsidies, integrating the islands of low transport traffic in as many routes as possible.

As far as the occupancy rates of ships are concerned, the trend that was emerging was their increase, as has already been said. By using the coastal company Nel Lines (we had enough statistical data, the company had a very high turnover, and it was listed on the ASE) we found on the one hand the occupancy rates in all coastal routes operating and on the other the occupancy rates in coastal route "Piraeus-ChiosMytilini" (the route with the highest passenger traffic for this company) (Tables 4 and 5).

It is a fact that taking into account the activity of the company as a whole, we do not lead to reliable results (Table 4). GCS includes several sub-markets (routes) which should be analyzed separately (Goulielmos and Sitzimis, 2014; Sitzimis, 2021a). However, we note that after the partial liberalization of the market (2002), the company's occupancy rate shows a decrease over time. We would interpret the above development as a consequence of the increasing competition in the main line of company's activity (Piraeus-Chios-Mytilene). This is one of the reasons why we have studied this line more thoroughly (Table 5). We reached the conclusion that after the year 2002, that is, in the early stages of cabotage removal, the occupancy rates of company's ships, on this route, showed a significant decrease ${ }^{5}$. It is characteristic that between 2005-2006, the drop is approximately $40 \%$ (mainly due to the decrease in passengers handled). We would therefore say that despite the effort of CSO to increase occupancy rates after liberalization, the intensity of competition can lead to exactly the opposite results.

5 These resulting coefficients relate to the whole year (average). It is certain that in the summer they appear much higher than in the winter. In some lines, e.g. "Piraeus - Chania", occupancy rates reaches $100 \%$ in times of high demand (peak). 
Table 4: Calculating the occupancy rates for "Nel Lines" in all coastal routes operating (2000-2007)

\begin{tabular}{|c|c|c|c|}
\hline Year & $\begin{array}{c}\text { Number of } \\
\text { passengers per } \\
\text { route }\end{array}$ & $\begin{array}{c}\text { Average of capacity } \\
\text { of ships in } \\
\text { passengers }\end{array}$ & $\begin{array}{c}\text { Occupancy } \\
\text { Rate }\end{array}$ \\
\hline 2000 & 453 & 1,152 & 0.39 \\
\hline 2001 & 488 & 1,255 & 0.39 \\
\hline 2002 & 620 & 1,234 & 0.50 \\
\hline 2003 & 615 & 1,298 & 0.47 \\
\hline 2004 & 584 & 1,298 & 0.45 \\
\hline 2005 & 607 & 1,298 & 0.47 \\
\hline 2006 & 587 & 1,250 & 0.47 \\
\hline 2007 & 334 & 895 & 0.37 \\
\hline Average & 536 & 1,210 & 0.44 \\
\hline
\end{tabular}

Source: Sitzimis, 2012.

Note: The occupancy rates came from the division of passengers per route with the average capacity of ships in passengers. We note that company's itineraries increased between 2006-2007, due to the purchasing of C-Link company and the following use of its ships (Panagia Tinou, Panagia Thalassini, Panagia Hazoviotissa). For this reason, the occupancy rates are lower in 2007 (about -21\%).

The concentration rate of GCS has been high over time (Lekakou, 2007; Sitzimis, 2012). The four largest (based on the average sales over time) companies in the sector (Minoan lines, Anek lines, Nel lines, Hellenic Seaways) consistently covered about $73 \%$ of the total market (between 1999-2008), while the prices of the Herfindahl index (HHI) showed remarkable stability (average prices of 0.18) (Goulielmos and Sitzimis, 2012). In fact, between 2006-2008 (i.e. after full market liberalization), the concentration rate of the four largest companies (CR4) increased by $2 \%$ (Goulielmos and Sitzimis, 2012). The same thing happened with the HHI index, which began to show an increasing trend (in fact immediately after 2003). If we also consider the participation of some of these companies (through the holding of a large percentage of shares) in the rest of the companies in the sector, we see the definitive tendency for the market to shrink in 4-5 groups of companies (Sitzimis, 2012). 
Table 5: Calculation of occupancy rates in coastal route "Peiraeus-Chios-Mitilini" for "Nel Lines" (2000-2006)

\begin{tabular}{|c|c|c|c|}
\hline Year & $\begin{array}{c}\text { Passengers' Number } \\
\text { per route }\end{array}$ & $\begin{array}{c}\text { Average of capacity } \\
\text { of ships in passengers }\end{array}$ & $\begin{array}{c}\text { Occupancy } \\
\text { Rate }\end{array}$ \\
\hline 2000 & 827 & 1,922 & 0.43 \\
\hline 2001 & 772 & 1,922 & 0.40 \\
\hline 2002 & 908 & 1,922 & 0.47 \\
\hline 2003 & 882 & 1,922 & 0.46 \\
\hline 2004 & 855 & 1,922 & 0.45 \\
\hline 2005 & 783 & 1,922 & 0.41 \\
\hline 2006 & 503 & 2,044 & 0.25 \\
\hline Average & 790 & 1,939 & 0.41 \\
\hline
\end{tabular}

Source: Sitzimis 2012.

Note: In 2006 the occupancy rates were much lower (about $-40 \%$ ) because of the considerable reduction of passengers' traffic on this route.

Of course, the value of HHI $(0.18<2)$ does not mean that GCS was either a perfectly or monopolistically competitive market at that time period (Besanko et al, 2010). The analysis should be done by coastal line (Sitzimis, 2021a-b-c). Considering the HHI indicators for five of the main coastal lines of the Aegean ${ }^{6}$, we found that the average of this indicator in terms of passenger traffic, private vehicle and truck traffic, ranged around 0.54, which is an indication of an oligopolistic market (Goulielmos and Sitzimis, 2012). It is obvious, then, that most markets in GCS are oligopolistic (and perhaps duopolistic, as in some of them HHI>0.6) (Goulielmos and Sitzimis, 2012; Lagoudis et al, 2011; Sitzimis, 2012; 2021c).

In relation to the financial condition of coastal companies after the full liberalization of the market (2006) and by taking into account the six largest companies (in terms of turnover) we concluded that the turnover of coastal companies increased by $17.24 \%$ after the full liberalization of GCS (2006-2008) (table 6). This was mainly due to the readjustment of coastal shipping fares (they increased after the lifting of Cabotage privilege). Their short- and long-term liabilities decreased by $4.87 \%$. They showed a declining trend, after the year 2002 (except for 2005) mainly due to companies' efforts to improve their financial statements. Up to that point, the increase was strong due to the high borrowing of the companies. Between 20052008 there is a decrease over time, with the exception of 2007 due to the significant increase in blue star ferries' obligations.

The companies' own funds increased by $6.87 \%$ and their expenses (ship operation costs, administration and disposal costs, financial expenses) by $39.58 \%$. Equity showed a downward trend between 2000-2004 (mainly due to losses from the depreciation of holdings and securities, annual economic losses, revaluations of

${ }^{6}$ We chose the coastal lines (1) Piraeus - Chania, (2) Piraeus - Chios - Mytilene, (3) Piraeus Heraklion, (4) Piraeus - Cyclades, (5) Piraeus - Dodecanese, due to the high transport traffic they present over time and the availability of statistical data for them. 
ships and securities and the reduction of accounts "share premium account" and "retained earnings"). After 2004 they began to increase (due to the increase in profits), while only in 2008 there is a small decrease (due to the declining profitability of coastal companies). Total expenses show relative stability between 2001-2004 with an upward trend after liberalization (mainly due to investments of coastal companies in high demand lines and the increase in fuel prices). For fuels in particular, the price of oil increased by $36 \%$ between $2004-2005$ and by $21 \%$ between 2005-2006 (Lagoudis et al, 2011; NBG, 2009; Sitzimis, 2012). Fixed capital showed a marginal increase of $0.38 \%$, with their average recording a decrease until 2007 (due to the gradual reduction of the coastal fleet-requirements for lower age limits) and an increase in 2008 (mainly due to the adjustment of the financial statements of Nel Lines).

Table 6: The financial data (in $€$ million) of the main companies of GCS (1998-2008)

\begin{tabular}{|c|c|c|c|c|c|c|}
\hline Year & Income & Expenses & Liabilities & Equity & Fixed capital & Net profits \\
\hline 1998 & - & - & 356.47 & 435.03 & 616.85 & 53.88 \\
\hline 1999 & 320.88 & 256.40 & 516.37 & 790.67 & 877.75 & 71.77 \\
\hline 2000 & 479.35 & 486.30 & $1,178.72$ & $1,386.14$ & $1,949.00$ & 1.98 \\
\hline 2001 & 528.14 & 567.30 & $1,486.92$ & $1,087.79$ & $2,247.15$ & -218.08 \\
\hline 2002 & 581.58 & 547.70 & $1,574.91$ & 913.39 & $2,099.19$ & -156.58 \\
\hline 2003 & 604.63 & 539.80 & $1,533.23$ & 852.88 & $1,938.18$ & 21.70 \\
\hline 2004 & 595.86 & 535.60 & $1,521.50$ & 834.39 & $1,822.96$ & 7.48 \\
\hline 2005 & 606.92 & 567.07 & $1,576.37$ & 846.20 & $1,847.61$ & 26.59 \\
\hline 2006 & 709.19 & 600.26 & $1,250.70$ & 933.24 & $1,714.09$ & 91.72 \\
\hline 2007 & 754.33 & 713.07 & $1,425.19$ & $1,020.98$ & $1,624.71$ & 71.26 \\
\hline 2008 & 831.45 & 837.83 & $1,189.85$ & 997.28 & $1,720.46$ & 23.59 \\
\hline Average & 601.23 & 565.13 & $1,237.29$ & 918.00 & $1,678.00$ & -0.43 \\
\hline & & & & & & \\
\% change \\
between
\end{tabular}

Source: Sitzimis, 2012.

For all companies, their net results deteriorated by $74.28 \%$, mainly due to the increase in expenses (2006-2008). In particular, there is an increase in profits from 2001 to 2006 (with the exception of year 2004, mainly due to very high fuel prices) and then a fall. Over time, however, profits show an increase (2001-2008). Particularly important was the restructuring of their loans, the implementation of effective management methods and the reversal of banks' attitudes towards the financing of the sector. 


\section{Liberalization and pricing effects in AVI}

The liberalization of the aviation industry led to a decrease in ticket prices, resulting in the preference of passengers for more air travel (IATA, 2007). However, this was not a panacea as there were oligopoly phenomena and hidden cartels that led to high charges (Papatheodorou, 2008). In the context of the liberalized market, "price discrimination" and "loyalty programs" (FFP) (Stavins, 2001) were developed. It is a fact that in a perfect competitive market, companies are not able to apply price discrimination. On the contrary, a monopolist, assuming that he is aware of, or even indifferent to users' preferences, does not avoid such strategies (Stavins, 1996). One would therefore expect that the more concentration in a market increase, so does price discrimination. But the reality sometimes differs. Borenstein (1985), Holmes (1989), and Gale (1993) have come up with exactly the opposite results in their studies in relation to the aviation industry.

Graham et al. (1983) looking at the pricing impact of liberalization on the U.S.A. domestic aviation industry, found mixed results. Fares have been increased for short-distance journeys. As the distance and the number of passengers carried increased, fares were reduced. Competition increased the frequency of discounts to passengers, thereby reducing the average fare.

Dresner and Tretheway (1992) were engaged in the study of a number of international air routes between 1976-1981 in order to ascertain the effects of liberalization on passengers. The removal of interventionism led to a reduction in fares, in economy classes, by about $35 \%$. On the other hand, it did not significantly affect the fares of the first and professional class. Maillebiau and Hansen (1995), between 1969-1989, found something similar for the Northern-Atlantic routes. Their research on the effects of liberalization on the users' surplus showed a reduction in fares of $35 \%$ to $45 \%$.

Kahn (2002) pointed out that the two most important advantages of liberalization worldwide are lower fares and higher efficiency. He estimated that liberalized fares are on average $10 \%$ to $18 \%$ lower than the period of cabotage existence. It states that the fare per mile is much higher on low-demand and competitive routes, while fares on the routes served by the eight busiest hub airports are almost 19\% higher than on routes served by other airports.

Rietveld, Schipper and Nijkamp (2001) analyzed the effects of the liberalization of AVI for users on selected European routes between 1988-1992. These lines are related to different capacity demand intensities and distances, while this period concerns varying degrees of deregulation, per air route. They concluded that fares of economy classes are $34 \%$ lower than the pre-existing period of state intervention in the market.

Wilfred (2006) studied ten lines in the Philippines, with varying characteristics and levels of competition, between 1981-2003. He concluded that the average fare per kilometer, on routes with at least two companies, is $10 \%$ lower. 
Considering that the twenty-three routes (90\% of passenger traffic) have only two companies, someone could conclude that most passengers benefit from the liberalization of the market.

\section{Liberalization and pricing effects in GCS}

As far as the variation of fares before and after the liberalization of AVI is concerned, the conclusions could, under certain conditions, be matched to GCS (mutantis mutandis). The example of a related industry, such as AVI, shows that the liberalization of the market leads to a reduction in fares, to higher efficiency and to an increase in the surplus of users. The fare per mile is much higher on low demand lines. Competition has increased the frequency of discounts to passengers, reducing the average fare. The removal of interventionism led to a reduction in fares in economy classes. On the other hand, it did not significantly affect the fares of the first and professional class.

However, the above findings do not have universality. At GCS, although there were discounts and offers (after 2009), fares did not decrease (Sitzimis, 2012). Ticket prices of conventional ships increased after the liberalization (between 2006-2010) and the average increase percentage was 49\% (Sitzimis, 2021c). Also, for highspeed vessels increases took place but were smaller (about 21,5\%). This is caused by the fact that these prices were already high before the liberalization of the market. The highest ticket prices and the biggest increase of prices is presented in itinerary "Piraeus-Rhodes" (a long-distance route of approximately 239 nautical miles). We reach the conclusion that the bigger the distance (and demand) the higher the fares are in GCS (Goulielmos and Sabrakos, 2002; Goulielmos and Sitzimis, 2014; Sitzimis, 2021c).

More specifically, during the period 2001-2008, fare of coastal companies increased by $43 \%$ (NBG, 2009). This fact made passengers lose their hopes of cheaper travelling after 2006 (Lekakou, 2007). Two months after the liberalization (July 2006) ticket prices increased in almost all coastal routes, with an average percentage increase for passengers 8,6\% and for private vehicles 2,7\% (Goulielmos and Sitzimis, 2012). The same thing happened in Argosaronikos routes (10.7\% and $4.8 \%$ respectively). In 2007, the high and continuously rising fares, raised even more in July and August, especially for island destinations of Cyclades and Dodecanese (in peak periods) (Goulielmos and Sitzimis, 2012; Sitzimis, 2021a).

Coastal ship-owners supported, before 2006, that fares were $40 \%$ lower than the average of EU (Sitzimis, 2012; 2021c). This was their main argument for raising fares (along with high fuel prices). However, comparing ticket prices, based on milemetric distances, in Greece and Europe (high-speed ferries), we found different reasons for the increase in fares in GCS after its liberalization. Fare variations between European and Greek itineraries, for almost the same distances (2008), ranged from $€ 21,5$ to $€ 105,5$ (Goulielmos and Sitzimis, 2014). The average deviation in absolute terms was about $60 €$ and in percent $58 \%$. As a rule, the level of fares was particularly high in GCS, compared to the rest of Europe. So the 
argument of CSO was inaccurate (Goulielmos and Sitzimis, 2014; Sitzimis, 2012). Furthermore, some people (Lekakou et al, 2011; NBG, 2009) consider that high ticket prices caused because of the increase in fuel prices. But this was not the only reason (Sitzimis, 2012). The anticipated competition, after the removal of cabotage privilege, didn't have a prompt positive effect to fares. Some evidence of competition emerged in the summer of 2010 (Sitzimis, 2021c).

The Study of the National Bank of Greece (2009) considered that the differences in ticket prices were mainly due to the peculiarities of Greek coastal system network, combined with the high fixed cost, which is a key feature of the sector. The relatively short distances traveled by ships in the Aegean Sea and the resulting lesser use over long-haul routes, make it difficult to cover the high fixed costs and therefore lead to a higher total cost per mile. That's why CSO cited that companies in order to maintain positive profit margins, a higher ticket was required in GCS. Of course, the above were not really the case and the causes of the increase in ticket prices had to be sought elsewhere. The expected competition, after the lifting of cabotage privilege, had not had a beneficial effect on fares in the first place (until 2010) and the degree of concentration on various coastal lines was still very high. Most of GCS lines continued to appear strongly concentrated (Goulielmos and Sitzimis, 2012).

The question is whether the higher concentration of the market shapes price discrimination in the coastal shipping industry. In air transport, as we have shown, the results are ambiguous. Price discrimination has been considered a way to extract as much profit as possible from each category of users, given their utility functions and income (Cole, 2006). In other words, it is associated with rising prices for less "sensitive" users. However, in the case of GCS's companies, the price discrimination occurs mainly through discounts on fares. Discounts given to users with the greatest elasticity of demand in terms of price. In this case, if higher competition reduces fare to "sensitive" users, it may lead to greater price discrimination. A transport industry could choose to price some passengers (mainly tourists-elastic demand) according to marginal cost (MC) and some other passengers (mainly professionals-inelastic demand) with higher prices (Cole, 2006). But there is also the opposite possibility. Price discrimination to be reduced. As the market becomes more competitive, companies may price all their services increasingly close to the $\mathrm{MC}$, leading to less price discrimination. This of course would have a direct impact on their profitability, as in GCS the AC $<\mathrm{MC}$, due to economies of scale (Sitzimis, 2021b). In addition, AVI prices vary depending on the period and depending on the time that elapses between the booking of the ticket and the flight (usually the larger this, the cheaper the ticket). This is not necessarily the case in GCS. The main benefit of the passenger with early ticket reservation is to secure a seat on board the ship (even during peak periods) and not the lower price. Finally, in Greece, after the liberalization of the market, the two means of transport seem to become more competitive with each other. Using the averages of passenger ticket prices and ascertaining travel time to the destination, we found discrepancy in the average prices of GCS and AVI (Figure 1). On some routes, the deviation of 
ticket prices ranges from $€ 24.3$ to $€ 64$.1. We consider that if we take into account the shortest travel time to destination (AVI) and the consumption costs onboard (e.g. food and entertainment costs because of GCS longer journey), the differences are minimized and their substitution is confirmed after liberalization. Of course, such an analysis requires an econometric approach in order to establish the value of the cross elasticity of demand for the two modes of transport. However, Spathi (2005) and Tsekeris (2008) confirm the above conclusion for the same routes.

Figure 1: Comparison of average fare in GCS and AVI $(6 / 7 / 2009$ - the amounts are in $€)$.

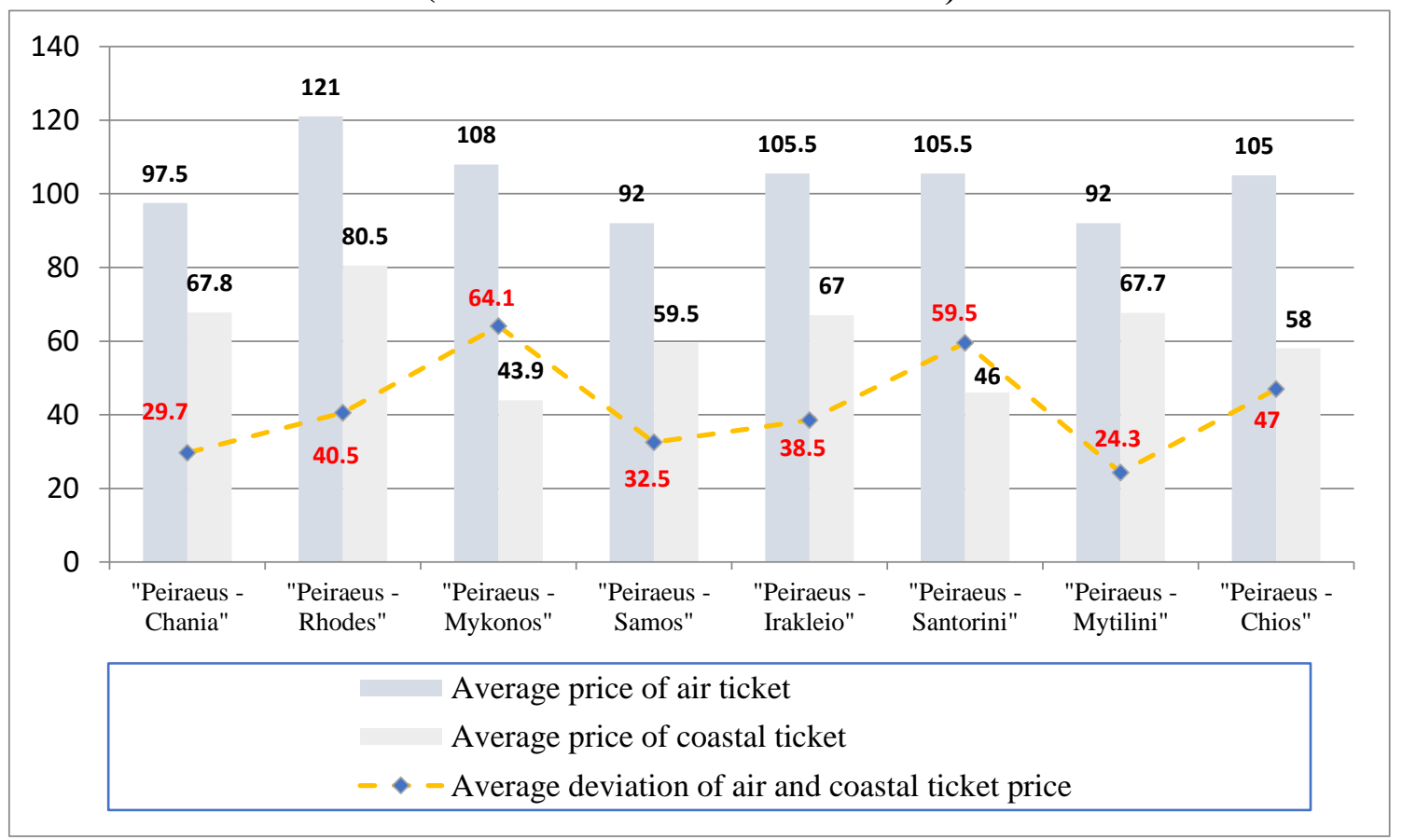

Source: Sitzimis, 2012.

Note: The routes "Piraeus-Mykonos" and "Piraeus-Santorini" present naturally an intense demand.

\section{Conclusions and discussion}

The institutional framework and the economic market conditions, immediately after the liberalization of AVI and GCS, show both similarities and differences. The lifting of cabotage privilege occurred for AVI market of America in 1978, for AVI market of Europe in 1999 and for GCS partially in 2002 and fully in 2006.

In AVI, the entry of new companies was difficult, with the exception of the first years of liberalization. These were mainly smaller companies that were more complementary. Traditional carriers were mainly active in hub-and-spoke networks while LCCs were active in point-to-point networks. With the development of hub-and-spoke networks, occupancy rates for traditional carriers increased (economies of scale have increased). The air network was strengthened and there was no apparent decrease in routes. In fact, new routes and new tourist destinations 
were created. Along with the drop in fares they made the air trip accessible to a larger portion of population. Only some remote islands with low air demand left without air service, which led to state subsidies. The quality of services provided probably deteriorated, due to companies' tendency to reduce costs. Overcrowding and delays in central airports were serious drawbacks. Also, LCCs and Charter companies minimized the services provided to passengers and traditional carriers proceeded to "quality distinction" (economy and business class). There has been an increase in capacity demand for AVI companies, an increase in their economic efficiency and an increase in the surplus of consumers (with a stable surplus of producers). The "cream skimming" policy was pursued in business, with clear orientation for the high-demand routes. Finally, there was an over-investment in capacity and an increase in profits, mainly in European market.

GCS during the partial liberalization (2002-2006) saw an increase in routes from ships of smaller tonnage (instinctive reaction of the CSO), while after 2006 the increase was greater. The coastal network was complicated (delays, overcrowding) due to conflict of CSO targets, state aspirations and lack of ships. Typical was the poor coastal connection in many low demand islands because of "cream skimming" CSO strategy. The immediate consequence was the creation of intense problems for permanent residents and the increasing granting of state subsidies. There were sales and an increase in average age of coastal ships (Law 2932/2001). Also a decrease in capacity demand after 2006 and an increase in the period 2002-2006. The degree of market concentration continued to be high, with a tendency to shrink in 4-5 groups of companies. In some routes, despite the effort of CSOs to increase occupancy rates, there has been a decrease due to stronger competition or oversupply of capacity. Finally, companies recorded an increase in sales, a decrease in liabilities, an increase in equity and expenses, a marginal increase in fixed capital and an increase in profits.

In relation to fares, AVI has had a decrease in ticket prices (mainly for economy class), although not always. Oligopolistic situations (cartels) have emerged with "gentlemen's agreements" for price increases and not so much for capacity issues. Price discrimination, loyalty programs and discounts took place on various routes and were not necessarily due to the increase in market concentration degree. In fact, competition led to some discounts (see early ticket booking) that reduced the average fare. Prices were higher at hub airports, while with an increase in travel distance or passengers transferred, there were also decreases. The more companies on a route, the average fare per kilometer was lower. The fare per mile was much higher on low demand routes. The existence of economies of scale presupposed pricing greater than MC.

GCS faced a raise in ticket prices, with a greater increase in conventional ships than in high-speed ships. The longer the distance, the higher the ticket price. The price discrimination occurred mainly in the form of discounts to passengers with a high elasticity of demand, while the early booking of a ticket did not entail a discount but a seat on board. As in AVI, MC-based pricing was not appropriate as it would lead the coastal companies to losses. The average deviation of ticket prices was $58 \%$ 
or $€ 60$ for Greece and Europe and for the same distances. Even if both high fuel prices and high total cost per mile prevented the reduction of fares, the expected competition (due to liberalization) had not had a positive effect until 2010 (high market concentration).

Finally, the two modes of transport become more competitive with each other with slight variations in fares.

\section{References}

[1] Besanko, D., Dranove, D., Schaefer, S. and Shanley, M. (2010). Economics of Strategy. International Student Version, 5th ed., John Wiley \& Sons Inc., New Jersey.

[2] Bieger, T., and Wittmer, A. (2006). Air transport and tourism-Perspectives and challenges for destinations, airlines and governments. Journal of Air Transport Management, 12, pp. 40-46.

[3] Borenstein, S. (1985). Price Discrimination in Free-Entry Markets. RAND Journal of Economics, vol. 16 (Automn), pp. 380-97.

[4] Button, K. (1998). Opening U.S. Skies to Global Airline Competition. Trade Policy Analysis, Nov.24.

[5] Brueckner, K., Goebel, A. and Niskanen, E. (1997). Airline deregulation: The American experience and prospects for Europe. (C, ISSN 0788-5016, No. 149) ISBN 951-561-214-4, Valtion taloudellinen tutkimuskeskus, Government Institute for Economic Research, Finland.

[6] Caves, D., Christensen, L. and Tretheway, M. (1987). An assessment of the efficiency effects of US airline deregulation via an international comparison. In E. Bailey (ed.): Public regulation: New perspectives on institutions and policies, Mass: MIT Press, Cambridge.

[7] Cole, S. (2006). Applied transport economics. Policy, management and decision making. 3rd ed., Kogan page, London.

[8] Douglas, G. and Miller J. (1974). Economic regulation of domestic air transport: Theory and policy. Brookings institution, Washington.

[9] Dresner, M. and Tretheway, M. W. (1992). Modeling and testing the effect of market structure on price. The case of international air transport. Journal of transport economics and policy, 26(2), pp. 171-184.

[10] Forsyth, P. (1997). The gains from the liberalization of air transport. A review of reform. Journal of transport economics and policy, Volume 32, part 1.

[11] Frank, R. (1983). When are prices differentials discriminatory?. Journal of policy analysis and management, 2, pp. 238-255.

[12] Fu, X., Oum, T. H., and Zhang, A. (2010). Air transport liberalization and its impacts on airline competition and air passenger traffic. Transportation Journal, 49(4), pp. 24-41.

[13] Gale, Ian L. (1993). Price Dispersion in a Market with Advance - Purchases. Review of Industrial Organization, vol. 8 (August), pp. 451-464. 
[14] Goulielmos, A. and Sabrakos, E. (2002). Coastal and short sea shipping. Stamoulis publications, Peiraeus.

[15] Goulielmos, A. and Sitzimis, I. (2014). The Liberalization process of the Ferry System in Greece, 2001-2009: What have been the benefits to users of Aegean Sea Transportation?. Spoudai Journal, 64(4), pp. 39-66.

[16] Goulielmos, A. and Sitzimis, I. 2012. Measuring market concentration in the Aegean Ferry System. Spoudai Journal, 62(1-2), pp. 7-27.

[17] Graham D. R., Kaplan D. P. and Sibley D. S. (1983). Efficiency and competition in the airline industry. Bell Journal of Economics and Management Science, 14(1), pp. 118-138.

[18] Hellenic statistical authority (Elstat), (2000-2010) [Online] https://www.statistics.gr/el/statistics/-/publication/SMA06/- [Accessed 25/09 September 2021].

[19] Holloway, S. (2006). Straight and level: Practical airline economics. 2nd ed., Ashgate publishing Ltd, Aldershot.

[20] Holmes, T. J. (1989). The Effects of Third-Degree Price Discrimination in oligopoly. American Economic Review, vol. 79 (March), pp. 244-250.

[21] IATA. (2007). Airline Liberalization. IATA Economics Briefing No 7. https://www.iata.org/en/iata-repository/publications/economic-reports/airlineliberalization// [Accessed 27/09 September 2021].

[22] Johnson, R. L. (1995). Networking and market entry in the airline industry. Journal of transport economics and policy, 19(3), pp 299-304.

[23] Kahn, A. E. (2002). Airline Deregulation. Henderson, D. R. Editor. The Concise Encyclopedia of Economics, Liberty Fund Inc, Indianapolis.

[24] Koran, D.W. (1983). The welfare effects of airline fare deregulation in the United States. Journal of transport economics and policy, 17(2), pp. 177-189.

[25] Lagoudis, I., Lekakou, M., Thanopoulou, H. and Pantelaros, I. (2011). Evaluating ferry services through an AHP estimated KPI system: a focus on central Aegean. International Journal of Decision Sciences Risk and Management 3(1/2). Doi:10.1504/IJDSRM.2011.040752

[26] Lainos, I. (1999). Air Transport Economics. Stamoulis publications, Athens.

[27] Lekakou, M. (2007). The eternal Conundrum of Greek Coastal Shipping. In Pallis, A. A., (ed.), Maritime Transport: The Greek Paradigm Research in Transportation Economics Series, No 21, Elsevier, London.

[28] Lekakou, M., Pallis, A., Vaggelas, G. and Vitsounis, T. (2011). Users' speak: Coastal shipping services and islanders. Conference: European Conference on Shipping Intermodalism and Ports, Chios, Greece.

[29] Maillebiau, E. and Hansen, M. (1995). Demand and consumer welfare impacts of international airline liberalization: The case of North Atlantic. Journal of transport economics and policy, 29(2), pp. 115-136.

[30] Morrison, S. and Winston, C. (1995). The evolution of the airline industry. Brookings Institution, Washington.

[31] National Bank of Greece (NBG). (2009). https://www.nbg.gr/greek/thegroup/press-office/e 
spot/reports/Documents/Coastal\%20shipping\%20January\%202009.pdf [Accessed 28/09 September 2021].

[32] Oum, T.H., Park, J.H. and Zhang, A. (2000). Globalization and Strategic Alliances: The Case of the Airline Industry. Elsevier Science.

[33] Papatheodorou, A. (2008). The impact of Civil Aviation Regimes on Leisure Travel. In A. Graham, A. Papatheodorou and P. Forsyth (eds.), Aviation and Tourism: Implications for Leisure Travel. Ashgate Publishing Ltd.

[34] Peiraeus port authority (OLP). (1996-2007). https://www.olp.gr/el/statistikastoixeia/item/6676-kinisi-epivaton-trohoforon-eton-1996-2007. [Accessed 28/09 September 2021].

[35] Peterson, E. (2008). Open Skies: An Assessment of the US-EU Open Aviation Area. Paper presented at 11th Annual Conference on Global Economic Analysis Helsinki, Finland.

[36] Psaraftis, H. (2006). Aegean Ferry System and Cabotage. Eugenides Foundation Publications, Athens.

[37] Rubin, R. and Jou, J. (2005). Where Are the Airlines Headed? Implications of Airline Industry Structure and Change for Consumers. The journal of consumer affairs, 39(1). pp. 215-228. doi: 10.1111/j.1745-6606.2005.00010.x

[38] Rietveld, P., Schipper, Y. and Nijkamp, P. (2001). Estimating welfare effects of European airline liberalization. Presented at the 9th world conference on transportation research (WCTR) in Seoul, Korea, WCTR paper No. 1354, Revised 2002. Department of Spatial and Environmental Economics, Free University, Amsterdam, the Netherlands.

[39] Schipper, Y. and Rietveld, P. (1997). Economic and environmental effects of airline deregulation. Tinbergent Institute Discussion papers, 97-031/3, Faculty of economics, Free University Amsterdam, Holland.

[40] Seetanah, B., Sannassee, R. V., Teeroovengadum, V., and Nunkoo, R. (2019). Air access liberalization, marketing promotion and tourism development. International Journal of Tourism Research, 21(1), pp. 76-86.

[41] Sitzimis, I. (2012). Aegean coastal market: the consequences of cabotage privilege removal by microeconomic tools. Doctoral Thesis. University of Peiraeus, Athens.

[42] Sitzimis, I. (2021a). An optimal forecasting method of passenger traffic in Greek coastal shipping. Under review in international journal of business and economic sciences applied research (IJBESAR).

[43] Sitzimis, I. (2021b). Economies of scale in Greek coastal shipping. A survivor analysis, Under review in European Transport/Transporti Europei journal.

[44] Sitzimis I. (2021c). An implementation proposal of innovative pricing in Greek coastal shipping. Oradea journal of business and economics (OJBE), 6(2), pp. 69-77.

[45] Spathi, S. (2005). A comparison between air and coastal services in internal routes: An econometric estimation of demand. Center of programming and economical research, Athens. 
[46] Stavins, J. (1996). Price Discrimination in the Airline Market: The Effect of Market Concentration. Federal Reserve Bank of Boston.

[47] Stavins, J. (2001). Price discrimination in the airline market: The effect of market concentration. Review of Economics and Statistics, 83(1), pp. 200-202.

[48] Tsekeris, T. (2008). Consumer Demand Analysis of ComplementaritySubstitution Relationships Among Passenger Transport Modes in Greece. International journal of transport economics (IJTE), XXXV/3, pp.166. doi: 10.1400/99570.

[49] Wilfred, S. (2006). Airline Liberalization Effects on Fare: The Case of the Philippines. J Bus Res, doi:10.1016/j.jbusres.2006.10.019.

[50] Wittman, M. D., Allroggen, F., and Malina, R. (2016). Public service obligations for air transport in the United States and Europe: Connectivity effects and value for money. Transportation Research Part A: Policy and Practice, 94, pp. 112-128.

[51] XRTC, (2005; 2006; 2009), Annual Research of Greek Coastal Shipping, XRTC Business Consultants, Athens. 